\title{
DEVELOPMENT OF A USER'S MANUAL FOR EXPERIMENTS IN BOUNDARY LAYER WIND
} TUNNEL.

\section{Elidi I. H. Paolini, Letícia O. Neves.}

\begin{abstract}
Wind tunnels are an important instrument to determine the influence of the wind on the building's design. Thereby, the main purpose of this research is to formulate a user's manual to help conducting experiments in the boundary layer wind tunnel of the Environmental Comfort and Applied Physics Laboratory at Unicamp. In the actual stage of this research, speed tests are being performed to calibrate a boundary layer profile. The results from the experiments are shown and analyzed by the comparison with data from published literature.
\end{abstract}

\section{Key words:}

Natural ventilation; Wind Tunnel; user's manual.

\section{Introduction}

The development of wind tunnel experiments is important to determine the influence of natural ventilation on the performance of building design, once qualitative and quantitative assessments can be conducted in this equipment by using small-scale models. Thereby, the main purpose of this research is to develop a user's manual to help conducting usual experiments of natural ventilation in the boundary layer wind tunnel of the Environmental Comfort and Applied Physics Laboratory (LaCAF), located at the School of Civil Engineering, Architecture and Urban Design, Unicamp. For that matter, a boundary layer profile calibration will be done by speed and pressure tests performed in the wind tunnel in question. The first part of the research consists in the speed tests, which are already being done. The pressure tests conform the second part and will be initiated once the speed tests are successful.

\section{Results and Discussion}

For the boundary layer profile calibration, firstly speed tests were conducted in order to verify the functionality of the already existing turbulence generators in the wind tunnel. The turbulence generator tested simulates the 3 rd category of surface's rugosity of NBR $6123^{1}$ (1988) which includes flat or undulating terrains with obstacles, such as hedgerows and walls, few trees, low-rise and sparse buildings.

For the speed measurement, four hotwire anemometers were placed inside the tunnel, in eleven different heights $(3 \mathrm{~cm}, 4 \mathrm{~cm}, 6 \mathrm{~cm}, 8 \mathrm{~cm}, 10 \mathrm{~cm}, 12 \mathrm{~cm}, 14 \mathrm{~cm}, 16 \mathrm{~cm}, 18 \mathrm{~cm}$, $31 \mathrm{~cm}, 46 \mathrm{~cm})$.

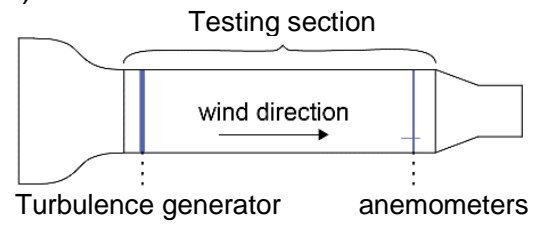

Image 1. Wind tunnel with turbulence generator and anemometers.

The data acquisition was made during $30 \mathrm{~s}$ with a rotation frequency of $400 \mathrm{rpm}$. The reference measure was taken with the tunnel turned off and the value was subtracted from the following measurements. For each height, three speed measures were made and the average was used to create the slope of image 2 .

For the actual stage of this research, the results obtained from the speed tests were compared to the ones presented in the literature ${ }^{2,3}$. A standard slope was drawn from the Power Law:

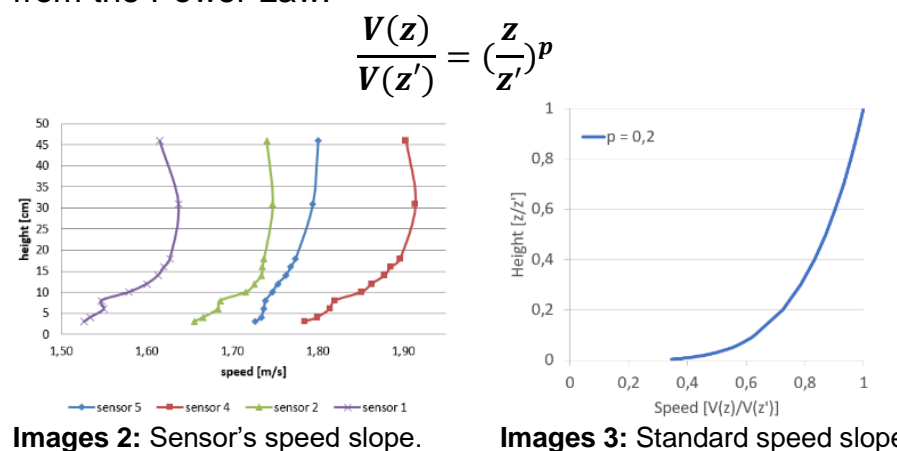

Images 2: Sensor's speed slope.

Images 3: Standard speed slope.

\section{Conclusions}

Comparing the results obtained from the speed tests in the wind tunnel with the data from the literature, it is a fact that the sensor's speed slope does not correspond to the standard speed slope. The unreliable results might be caused by a misuse of the data collecting software, the need of anemometer's calibration or even the malfunction of the sensors.

Before the next stage of this research, some of the tests will be remade in order to investigate potential causes of the inaccurate results. Following the succeeded speed tests, pressure tests will be done and subsequently the formulation of a user's manual of the wind tunnel will be continued.

\section{Acknowledgement}

This work was supported by Programa Institucional de Bolsas de Iniciação Científica e Tecnológica from UNICAMP and funded by Conselho Nacional de Desenvolvimento Tecnológico (CNPq).

\footnotetext{
${ }^{1}$ Associação Brasileira de Normas Técnicas. NBR 6123: Forças devidas ao vento em edificações. Rio de Janeiro, 1988.

${ }^{2}$ BLESMANN, J. Efeito do Vento em Edifícios. 2 ed., Porto Alegre, Editora UFRGS, 1989.

${ }^{3}$ BLESMANN J. O Vento na Engenharia Estrutural. Porto Alegre, Editora UFRGS, 1995.
} 